\title{
SETD2 Gene Mutation
}

National Cancer Institute

\section{Source}

National Cancer Institute. SETD2 Gene Mutation. NCI Thesaurus. Code C153504.

A change in the nucleotide sequence of the SETD2 gene. 